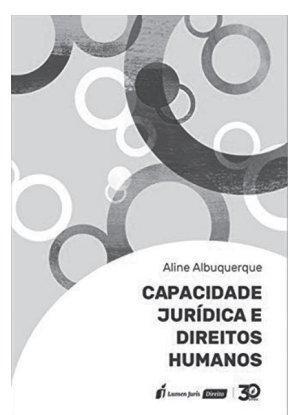

\title{
Albuquerque A. Capacidade jurídica e direitos humanos
}

\author{
Isis Laynne de Oliveira Machado'
}

DOI: 10.1590/0103-11042020E327

A POLÍTICA DE SAÚDE MENTAL, IMPLEMENTADA NO BRASIL na década de 1980, reconheceu a importância de adotar um modelo de cuidado que considere as necessidades, os desejos e as vontades das pessoas com sofrimento mental, objetivando sua inclusão social em ambientes de trabalho, lazer e cultura. Tal política fortaleceu-se com o advento da Lei ${ }^{\circ} 10.216 / 2001$, que visa proteger e garantir direitos de pessoas com transtornos mentais. Contudo, para que se alcance um bom modelo de cuidado e justiça social, é imprescindível a promoção da autonomia, da liberdade e da independência das pessoas com sofrimento ou transtorno mental.

Nesse sentido, a publicação do livro 'Capacidade jurídica e direitos humanos', da autora Aline Albuquerque, mostra-se fundamental para a discussão quanto aos meios de promoção da autonomia, proteção de grupos vulneráveis, compreensão do conceito de capacidade mental e avaliação do Modelo Legal de Capacidade Jurídica brasileiro, a partir do novo paradigma de capacidade jurídica ${ }^{2}$, alicerçado no referencial dos direitos humanos. A abordagem trazida nessa obra é inovadora no Brasil e nos introduz ao cenário mundial de discussões recentes, acerca da necessidade de encontrar um equilíbrio entre respeitar a autonomia e promover proteção de grupos vulneráveis, entre eles, pessoas com deficiência ou com transtornos mentais.

$\mathrm{Na}$ abertura da obra, a autora registra a importância de estudar os regimes da capacidade jurídica e mental, apoiados no referencial dos direitos humanos, considerando-os conceitos-chave no exercício da autonomia.

O primeiro capítulo trata da autonomia pessoal, perpassando por três modelos de autonomia, quais sejam:

a) autonomia tradicional, caracterizada pela ideia de autogoverno e soberania pessoal, da qual advém o princípio do respeito à autonomia, ancorado nas perspectivas de Kant e Mill. Referese ao dever do Estado ou de outrem em não interferir no corpo ou nas escolhas, vontades e crenças individuais;

1 Universidade de Brasília (UnB), Faculdade de Ciências da Saúde, Programa de PósGraduação em Bioética - Brasília (DF), Brasil. isis_laynne@hotmail.com

b) autonomia relacional, fundamentada nos valores de interdependência e interconexão entre as pessoas. Considera-se que a identidade individual é formada a partir das relações travadas entre as pessoas e o contexto em que vivem. Assim, sua interação com o meio externo se reflete na tomada de decisões. Quanto a esse modelo, a autora chama atenção para a existência de relações abusivas e opressoras, que podem limitar a autonomia individual; 
c) autonomia como promoção, cuja ideia central diz respeito ao reconhecimento da necessidade de adotar meios e instrumentos para enfrentar contextos abusivos e opressivos. O estudo defende que o modelo da autonomia como promoção é o mais adequado ao referencial dos direitos humanos, razão pela qual a proteção de adultos vulneráveis, como é o caso de pessoas com transtornos ou sofrimentos mentais, deve ocorrer a partir do modelo da autonomia como promoção.

No segundo capítulo, faz-se distinção entre capacidade jurídica e capacidade mental (decisional). A primeira "abarca o direito de ser titular de direitos - capacidade legal -, e a capacidade de ser um agente perante a lei agência legal"’(48). Ou seja, a capacidade jurídica diz respeito não só ao reconhecimento de que todas as pessoas são igualmente titulares de direitos, mas também de que possuem o direito de exercê-los, a partir de instrumentos que se adaptem à sua condição de vida. $\mathrm{A}$ capacidade mental, por sua vez, refere-se às habilidades determinadas pela lei, para que os indivíduos decidam acerca de sua própria vida. O estudo chama atenção para o fato de que a capacidade mental em nada se confunde com deficiência intelectual ou transtornos mentais, pois tal habilidade envolve o grau de entendimento inerente a determinada informação, para que o indivíduo possa decidir e compreender as consequências de sua escolha.

A autora apresenta diferentes abordagens e testes utilizados no mundo para a avaliação da capacidade mental. Defende que o critério dos 'melhores interesses' deve ser substituído pelo critério das 'vontades e preferências' do indivíduo, a fim de nortear o Regime da Capacidade Jurídica, pautada no referencial dos direitos humanos. Ressalta que a conjugação da capacidade jurídica e mental é importante para coibir atos de afronta à autonomia, especialmente de pessoas com deficiência ou transtornos mentais.

O terceiro capítulo trata do regime da capacidade jurídica sob a ótica do referencial dos direitos humanos. Examinam-se as abordagens da Tomada de Decisão Apoiada e da Tomada de Decisão Substituta. A primeira fundamenta-se na promoção da autonomia pessoal. Diz respeito à adoção de suportes para auxiliar às pessoas na tomada de decisões, tais como suporte familiar, diálogo aberto, círculos de apoio, ombudsman pessoal, entre outros. A segunda refere-se à curatela, que, em regra, consiste na privação da capacidade jurídica de uma pessoa, para que outra decida em seu lugar. Ela é conferida por meio de decisão judicial e, geralmente, tem como consequência a privação ao exercício autônomo dos direitos do indivíduo à propriedade, ao casamento, ao voto e à vida familiar. $\mathrm{O}$ estudo aponta que, no Brasil, a curatela é concedida com base em diagnósticos de deficiência mental ou intelectual, ou de transtorno mental, sem a devida avaliação da capacidade decisional. A autora afirma que a abordagem da tomada de decisão substituta não condiz com o referencial dos direitos humanos, razão pela qual defende que a curatela deve ser utilizada como mecanismo residual, propondo a adoção de mecanismos de suporte para tomada de decisão, como meio de promover a autonomia.

No quarto capítulo, realiza-se revisão do modelo brasileiro de capacidade jurídica, perpassando pelos aspectos legislativos acerca da matéria, comparando-o com novos constructos do regime da capacidade jurídica pautado no referencial dos direitos humanos. Constata-se que o modelo brasileiro necessita de urgente adequação, a fim de avançar na discussão acerca da tomada de decisão e capacidade mental.

A partir da avaliação de decisões judiciais e da leitura crítica de artigos contidos na legislação civil brasileira, o quinto capítulo demonstra que o modelo utilizado no Brasil está em descompasso com modelos de outros países, tais como Irlanda, Áustria, Inglaterra e Estados Unidos da América (Texas e Delaware). Apontou-se que, no Brasil, pessoas constantemente possuem sua autonomia desrespeitada ao argumento de que necessitam ser protegidas pelo Estado ou por outrem, como é o caso das 
pessoas idosas, pessoas com deficiência ou com transtornos mentais. Por isso, a autora defende adotar um modelo de "capacidade jurídica centrado na pessoa enquanto sujeito e não como objeto da proteção do Estado"'(241).

Ao final, a autora reverencia os avanços trazidos pelo Estatuto da Pessoa com Deficiência no Brasil e aponta ser urgente a adoção de mudanças legislativas, que protagonizem os suportes para tomada de decisão no Modelo Legal de Capacidade Jurídica no Brasil. As discussões apresentadas são essenciais para a compreensão de que a capacidade jurídica é um direito absoluto. Tal entendimento mostra-se fundamental para promover alteração cultural e legislativa no Brasil, especialmente no campo de saúde mental, reconhecendo que pessoas com deficiência ou transtornos mentais não devem ser declaradas incapazes com base em sua doença, assim como pessoas com inabilidade decisional têm direito ao uso de mecanismos de apoio para tomada de decisão, de modo a preservar e promover sua autonomia.

\section{Colaboradora}

Machado ILO (0000-0003-0051-9307)* é responsável pela elaboração do manuscrito.

\section{Referências}

1. Albuquerque A. Capacidade jurídica e direitos humanos. Rio de Janeiro: Lumen Juris; 2018.

2. Committee on the Right of People with Disabilities. General Comment. Article 12: Equal recognition before the law [internet]. 2014. [acesso em 2020 fev 27]. Disponível em: https://documents-dds-ny.un.org/doc/UNDOC/GEN/G14/031/20/ PDF/G1403120.pdf?OpenElement.
Recebido em 01/03/2019

Aprovado em 25/08/2020

Conflito de interesses: inexistente

Suporte financeiro: o presente estudo foi desenvolvido com apoio

da Coordenação de Aperfeiçoamento de Pessoal de Nível Superior (Capes)/MEC 